\title{
Digital media practices in a conflict setting: Ukraine after the Maidan
}

\author{
(1) \\ Olena Nedozhogina \\ ORCID: 0000-0002-6422-5546
}

UNIVERSITY OF TARTU, ESTONIA

DOI: $10.19195 / 1899-5101.12 .3(24) .3$

\begin{abstract}
This article is a qualitative investigation of the mechanisms of reproduction of national identity narratives through digital media practices of hybrid populations in a conflict context using the example of Ukraine after the outbreak of the conflict with Russia. The article is based on a collection of 14 in-depth interviews with Russian-speaking Ukrainians from various regions. The findings point to several conclusions: first, hybrid/heterogeneous media practices are not always accompanied by high engagement. However, diverse (heterogeneous) and non-diverse (homogeneous) practices characterized by high engagement produced opposing narratives of national identity in the post-change Ukraine: a nation-centered interpretation of national identity (homogeneous) versus a universalistic post-national interpretation (heterogeneous).
\end{abstract}

KEYWORDS: Ukraine, digital media practices, identity, conflict, Russia.

\section{INTRODUCTION}

The interaction between the conflict context and digital media has been researched, though, mainly from the perspective of media's influence on political processes (Bennett \& Segerberg, 2012; Chadwick, 2017). However, there is evidence that digital media can not only play a role in the reinforcement of dominant identity narratives, but can also create such multicontextual interactions/spaces that challenge them (Collin, 2014; Vertovec, 2001). The population's engagement with hybrid digital practices (e.g., those crossing state borders), in particular, has been found to produce "new forms of loyalty" (Andersson, 2013). This article aims at exploring how strategies used to describe/justify engagement and non-engagement with heterogeneous digital media content can help uncover important tensions in the forming/solidifying national identity narrative in a conflict context. 
Ukraine experienced a major upheaval in 2013 with the Euromaidan Revolution and ensuing conflict with Russia (occupation of Crimea; military clashes in the Donbass region). On the one hand, the public narratives of Ukraine and Russia became violently opposed to each other and, arguably, more ethno-centric (Kuzio, 2015; Teper, 2016). Despite a long history of hybrid identifications in peripheral regions of Ukraine and the generally short distance between the main population groups (Ukrainian-speaking Ukrainians, Russian-speaking Ukrainians, Russians), the number of people identifying as "Ukrainian" by nationality rapidly increased to 90\% (Kulyk, 2019; Nedozhogina, 2019). The government introduced comprehensive restrictions on accessing main Russian media resources (over 100 channels, radio, main Russian-origin social media). Active boundary-making processes are taking place: the public discourse is concerned with distancing from Russia (in values, governance) and the population is experiencing consolidation of national identification (Nedozhogina, 2019).

On the other hand, no change has been recorded in the everyday language practices, and changes in media consumption are yet to become significant (Kulyk, 2019). The introduced restrictions do not prevent citizens from accessing Russian web resources via satellite TV or illegally. We can presuppose that the conflict introduced an additional dimension to hybridity, where now Ukrainian users have to reconcile their rising patriotic (and anti-Russian) sentiments with a heterogeneous digital media-scape, not completely separated from Russia, and their own everyday practices. The re-negotiation of the meaning of hybrid practices in the context of solidification of the symbolic border between Ukraine and Russia can be expected to produce new developments in the national identity discourse.

The recent scholarship on the topic of identity (Kulyk, 2018) and media use (Hutchings \& Szostek, 2015) in Ukraine mostly focused on media text, reaching general conclusions that (hybrid) practices of Russian-speaking Ukrainians (e.g., posting in Russian) are often essentialized by "outside" audiences, but are not seen by hybrid users themselves as a basis for their (national/cultural) identity. At the same time, the conflict-induced polarization is augmented by the proliferation of anti- and pro-Russian narratives in the media, with the population continuously engaging with both (Szostek, 2018). Therefore, the goal is to build on how users conceptualize heterogeneous practices that often involve encounters with pro-Russian narratives and what implications this has for Ukrainian national and civic identity discourse. I will do so by looking at practices through the lens of Reckwitz's (2002) and Shove and Pantzar's (2005) social practice theory, which sees practice as an embodied, habitual bundle of doings and sayings; as well as Couldry's (2012) definition of media-related practices as an open-ended range of doings oriented around media. The overall goal is to contribute to the scholarship on the effect of conflict on media consumption and also to develop Couldry's typology of media practices. 


\section{CHANGES IN UKRAINIAN MEDIA AFTER THE MAIDAN REVOLUTION}

The issue of media, language and its relation to identity in Ukraine remains contentious. On the one hand, following the annexation of Crimea and outbreak of the conflict in Donbass (2014), the public narratives of Ukraine and Russia became violently opposed to each other (Hutchings \& Szostek, 2015). This struggle manifested itself in the media-scape as well, with more than 100 Russian channels, TV shows and radio, as well as main social networks VKontakte and Odnoklassniki, email service Mail. ru and Yandex search - all of Russian origin — being banned in Ukraine as of 2017.

On the other hand, most of the banned sources are either available through satellite television (channels), internet (movies and TV series) or VPN services (platforms). Therefore, the resources were made less accessible, but not completely eliminated from the lives of the population. Table 1 summarizes scattered data about media usage in Ukraine before and after the crisis erupted (2014) and the ban was introduced (2017).

Table 1. Traditional and digital media in Ukraine

\begin{tabular}{|c|c|c|}
\hline \multicolumn{3}{|c|}{ Traditional media } \\
\hline & Before 2014 (conflict) & After 2014 \\
\hline $\begin{array}{c}\text { Share of newspapers in } \\
\text { Russian language out of total } \\
\text { newspaper circulation }\end{array}$ & $61.5 \%$ & $61.5 \%$ \\
\hline $\begin{array}{l}\text { Russian language magazines } \\
\text { out of total magazine } \\
\text { circulation }\end{array}$ & $85.6 \%(2014)$ & $62.6 \%(2016)$ \\
\hline $\begin{array}{l}\text { Russian language on leading } \\
\text { TV channels, share of total air } \\
\text { time }\end{array}$ & $50.3 \%(2013)$ & $34.4 \%(2016)$ \\
\hline \multicolumn{3}{|c|}{ Digital media } \\
\hline & Before 2017 (ban) & After 2017 \\
\hline $\begin{array}{l}\text { Users of Ukrainian internet } \\
\text { (domain .ua), share of the } \\
\text { general population }\end{array}$ & $\begin{array}{l}\text { Appr. 23\%, } \\
\text { Kyiv oblast is among the } \\
\text { highest ( } 60 \%) \text {, while among } \\
\text { lowest are Donetsk obl. (5\%), } \\
\text { Crimea }(2.8 \%)(2009)\end{array}$ & $64.7 \%(2017)$ \\
\hline $\begin{array}{l}\text { Russian origin websites in the } \\
\text { top } 10 \text { most popular } \\
\text { resources in Ukraine }\end{array}$ & $\begin{array}{l}\text { 3-4 Russian resources - } \\
\text { Vkontakte (\#2), Yandex } \\
\text { Ukraine (\#5), Odnoklassniki } \\
\text { (\#7), Mail.ru (\#8) (2016) }\end{array}$ & $\begin{array}{l}1 \text { Russian resource - Vkon- } \\
\text { takte }(\# 4)(2018)\end{array}$ \\
\hline $\begin{array}{l}\text { Vkontakte coverage of } \\
\text { Ukrainian internet } \\
\text { (domain .ua) }\end{array}$ & $50 \%$ of users & $30.8 \%$ of users \\
\hline
\end{tabular}




\begin{tabular}{|c|c|c|}
\hline $\begin{array}{c}\text { Odnoklassniki coverage of } \\
\text { Ukrainian internet } \\
\text { (domain .ua) }\end{array}$ & $22.3 \%$ of users & $17 \%$ of users \\
\hline $\begin{array}{c}\text { Interface language on } \\
\text { Facebook among Ukrainian } \\
\text { users }\end{array}$ & $\begin{array}{c}75 \%-\text { Russian language } \\
19 \%-\text { Ukrainian language } \\
6 \%-\text { other } \\
(2016)\end{array}$ & \\
\hline $\begin{array}{c}\text { Share of population using } \\
\text { Vkontakte (monthly) } \\
\text { as of 2017 }\end{array}$ & Appr. 33\% \\
\hline
\end{tabular}

Source: Author; data retrieved from: Association of Ukrainian Internet. (2018). Audience review. https://inau. ua/proekty/doslidzhennya-internet-audytoriyi; S. Svidlov. (2018). Ukrainian language on the Internet. Portal of Language Politics. http://language-policy.info/2018/10/ukrajinska-mova-v-interneti/; Alexa rating for 500 Top websites. Alexa. https://www.alexa.com/topsites/countries/UA; T. Shamayda. (2016). Yearly monitoring of Ukrainian language, performed by Freedom Space NGO; TNS Ukraine. (2018). Rating of popular websites. https://tns-ua. com/news/reyting-populyarnih-saytiv-za-serpen-2018; L. Belei. (2016). Ukrainian language online. Portal of Language Politics. https://language-policy.info/2016/12/3612/.

Overall, the role of the Russian language has been diminishing in the mediascape, however, not very drastically. Some Russian resources have lost their share of coverage due to the ban; on the other hand, the spheres of entertainment, consumption and communication are still dominated by the Russian language. In spite of restrictions, a third of the population still accesses VKontakte monthly. It is hard to deny that the Russian language plays a significant role in the Ukrainian digital media sphere, which means that, despite the conflict with Russia, the socio-technical system still supports hybrid and heterogeneous practices.

In order to understand how the conflict between Ukraine and Russia, as well as intensifying nation-building in Ukraine, affected the reproduction of the Ukrainian national identity discourse, I will look into users' digital media-related practices and their justification strategies through the lens of practice theory to see how hybridity is being conceptualized in relation to the concepts of nation and civicness (engagement).

\section{THE THEORETICAL FRAME}

Media as an important vessel for national identity construction is at the center of this research, following Anderson's conceptualization of nationhood as "imagined communities" - common virtual constructs that unite people who otherwise don't know each other, through information-spreading technologies, state commemorative practices, etc. (Anderson, 2006). However, in the context of rising mobility and porousness of borders/information, I also see national identity narratives as becoming increasingly negotiable, where hybrid practices might lead to the unfixing of identities - construction of such multiple identities that do not fit discourses perpetuated by respective nation states, and that, in fact, break out of the national frame (Aksoy 
\& Robins, 2002; Vertovec, 2001). In this article I want to see how national identity is being re-negotiated and reproduced via micro-level digital practices in the context of a hybrid media system - but also under the influence of the conflict-induced polarization (essentialization).

To achieve the above goal, I would like to move away from media texts and instead focus on practices, or, "what are people actually doing in relation to media?" (Couldry, 2012). Couldry has coined the concept of media-related practices, but up until now there were no efforts to develop the mapping further. By creating this mapping, I want to explore the dynamics of identity reproduction through media practices under conflict circumstances through two dimensions: homophily/heterophily and civic engagement across media-related practices.

For the purposes of this study I define heterophily, based on a more general tension outlined by Couldry (2012) between keeping channels open (heterophily) and screening out (homophily), as engaging with/producing content and activities that originate from countries other than Ukraine or from occupied/not controlled territories (Crimea, parts of Donbass), or which in any other way refers to "foreign" elements in the public discourse of Ukraine. Hybrid media/cultural practices (e.g., uniting elements of "Ukrainian" and "Russian," using languages interchangeably in creating posts, or bringing elements from the "other side" - e.g., pictures/news from the occupied territories - into the discourse) - can be considered challenging to the state narrative in the context of conflict and active nation-building. Homophily, conversely, is conceptualized as limiting engagement with cross-border and/or challenging content, as well as maintaining practices of engagement with homogenous (in a cultural sense) content (e.g., unsubscribing from groups/content creators from Russia; switching to Ukrainian (national language) in content creation, etc.). Communicative civic engagement is defined as instances of reflection on political/civic meanings of practices; civic references in rationalizations of practices and general conceptualization of practice goals in terms of transformativity (Wessels, 2018).

The "allure of homophily" (Gu, Konana, Raghunathan, \& Chen, 2014) is that people often seek familiarity/reassurance through their online practices. On the other hand, researchers have consistently associated heterophily with civic engagement, and it is generally accepted that more diverse and issue-oriented media practices lead to higher levels of civic engagement (see an overview in Gil de Zúñiga, Jung, \& Valenzuela, 2012). At the same time, it has been demonstrated that while hybrid communities tend to construct their news consumption from multiple sources, "like a puzzle," this does not often lead to taking up of alternative narratives (Szostek, 2017, 2018; Vihalemm, Juzefovičs, \& Leppik, 2019). Therefore, the influence of the conflict context on the way users engage in and rationalize heterogenic practices, as well as the impact of heterogeneity on the civic identity narrative, are the focus of this research.

To conduct the analysis and develop Couldry's (2012) concept of media-related practices further, I analyzed the identified activities based on three elements of social practice suggested by Shove \& Pantzar (2005): 


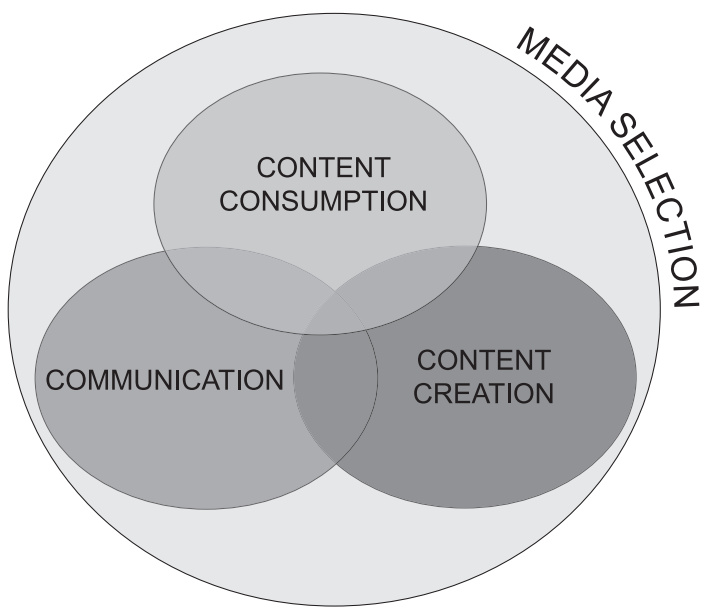

Figure 1. Mapping of media practices

Source: Author.

- Meaning - interpretation attached to the practice by users;

- Tools - the object necessary to perform the practice; and

- Skills - reflective and tacit competences needed to perform the practice.

Based on the analysis of the core elements (meanings, skills and tools), I identified four categories of practices: media selection practices, content consumption practices, content creation practices and communication practices, which echo some of the types of practice developed by Couldry (2012) and empirically described in the example of the Russian-language audience by Vihalemm, Juzefovičs, and Leppik (2019).

I defined media-selection practices as meta-practices (hence their position in Figure 1) that are aimed at shaping the totality of one's media architecture. Couldry speaks about searching and search-enabling practices: different strategies of how people "optimize their access to a vastly expanded flow of potentially relevant information" (Couldry, 2012, p. 32). This is also close to "searching and organizing practices" defined by Vihalemm, Juzefovičs, and Leppik (2019). The division of heterophily/homophily in this context is similar to the fundamental strategies of "keeping channels open" vs. "screening out" (Couldry, 2012), in other words - whether a user is prioritizing diverse, potentially challenging sources of getting information, as opposed to streamlined, single-narrative ones. I looked into rationalizations and interpretations attached to choosing some media platforms over others, subscribing/unsubscribing, etc. - activities focused on putting together a certain media "puzzle." These practices presupposed specific tools and skills - e.g., in a Ukrainian context, the ability to use a VPN for certain platforms.

Communication practices, in their turn, carried the meaning of conveying information between users privately. A wide variety of tools employed presupposed varying degrees of competences, in addition to the general knowledge of using 
specific resources. Moreover, conflict-imposed limitations (e.g., severance of mobile connections with occupied territories, blocking of $\mathrm{VK}$ ) made users adapt according to their level of competence. Heterophily here was conceptualized as engaging in communication with users carrying alternative narratives (e.g., from Russia and the uncontrolled territories (Crimea, Donbass).

I defined content consumption as practices of passive acquisition of information, accompanied by various meanings - news, entertainment, hobbies, etc. In this sense Couldry's (2012) and Vihalemm, Juzefovičs, and Leppik's (2019) "keeping up with the news" constitutes just one part of this broader category. Heterophily in this category was understood as consumption of content originating from foreign/uncontrolled territories and/or conveying a challenge to the mainstream (pro-Russian) narratives.

Content creation practices were defined as practices carrying the meaning of production of new information (posting, uploading pictures, etc.). Due to the interactive nature of tools involved (social network platforms), the content creation practices often contained a significant degree of communication (e.g., commenting). In this sense, the line between content creation and communication is blurry, although content creation mostly happens in the public sphere, while communication - in private. Content creation generally requires higher level skills (as well as aesthetic competence) than communication. Heterophily here was understood as producing content that challenged the state narrative and/or brought "alien" elements (e.g., re-conceptualization of uncontrolled territories) into the discourse.

Defined practices were mapped along the axes of the degree of homo-/heterophily and engagement. The analysis is presented by practice category, to illustrate various practices (low engagement homophily, low engagement heterophily, etc.) side by side, while enabling a better comparison. Strategies of rationalization are discussed to identify concepts and values that respondents refer to, as well as specific meanings attached to practices.

\section{METHODOLOGY}

The analysis is based on a collection of 14 in-depth interviews gathered in Kyiv in 2018. The snowball method was used; the main criteria for respondents involved Russian as the main language of communication, Ukrainian citizenship and higher education (expected more active digital media engagement). Most of the respondents also had Ukraine as a place of socialization during their formative years (12 out of 14 were born in Ukraine; one respondent was born in Russia but moved to Ukraine during middle school; only one moved later in life).

To get a more diverse sample of respondents, I made sure to include respondents from Eastern and Southern Ukraine - Donetsk/Luhansk (8 respondents) and Crimea regions ( 2 respondents), as these areas are located at the symbolic periphery between Ukraine and Russia (Kulyk, 2019). This provided additional value to the cross-cutting issues brought forward by respondents, as well as a thin context to 
the analysis. The interview format included semi-structured discussions on such topics as language practices, changes in the respondent's life after 2014, general media use, as well as interactive exercises recreating the morning online routine.

The size of the sample presupposes the non-generalizable character of the study, whereby providing a representative overview of distribution of various digital media practices across the population was not the ambition of my research. Rather, I aimed at investigating concepts, categories, and relationships between them, which would be impossible to grasp through quantitative data. The focus of this study is on the strategies of boundary-making and national identity narrative construction. To this end, I collected materials until the saturation point was reached, and no new information was coming in from the materials (in total, more than 31 hours of everyday communication speech were recorded). Specific interaction between various instruments of boundary-making provide an insight into the tension points of the current nation-building - and engagement with hybridity — in Ukraine.

\section{RESULTS}

\section{Media selection practices}

A mapping of media practices in relation to heterophily and engagement is provided in Table 2, with quotations for the purposes of illustration.

As for the different pulls and triggers that users are subjected to due to the conflict, the main conclusion is that they cannot be seen simply as passive "receivers." While institutional limitations and the audience can influence the form and message composition, the users were found to engage in influencing one's audience composition, eliminating opportunities for criticism. The user can choose one social network over another, subscribe and unsubscribe to groups/pages and, ultimately, decide who gets to show up on the feed and comment on the posts.

Respondents' accounts supported the assumption that some users value having multiple sources that produce opposing narratives, while others prefer to eliminate sources of unwanted information. However, both view any given digital media as a tool that needs to be shaped for one's needs:

To put it bluntly, they [active "friends" on social media - O. N.] do this work, in a sense that I don't have to sit down [and look through news - O. N.], not all news is interesting for me. And those which are interesting will reach me through the feed. I think it is boring to sit and specifically read through news. [Interview 9]

Respondents' narratives illustrated that selection practices can lead to more heterogeneous or homogenous mediated contacts with narratives and information feeds, and this can also be understood through the lens of engagement: with some activities being described as issues of comfort or entertainment, and others forming a basis for self-identification as a "knowledgeable citizen." This comes out more explicitly through rationalizations provided by respondents. 
Table 2. Findings: media selection practices

\begin{tabular}{|c|c|c|c|c|}
\hline & $\begin{array}{l}\text { Low engagement } \\
\text { homophily }\end{array}$ & $\begin{array}{l}\text { High engagement } \\
\text { homophily }\end{array}$ & $\begin{array}{l}\text { Low engagement } \\
\text { heterophily }\end{array}$ & $\begin{array}{l}\text { High engagement } \\
\text { heterophily }\end{array}$ \\
\hline Practices & $\begin{array}{l}\text { Switching to other } \\
\text { SM due to ban } \\
\text { (comfort). }\end{array}$ & $\begin{array}{l}\text { Switching to other } \\
\text { SM due to political } \\
\text { reasons. Unsub- } \\
\text { scribing from } \\
\text { groups with an } \\
\text { opposing narrative. } \\
\text { Subscribing to } \\
\text { groups to have more } \\
\text { desirable political } \\
\text { content in the feed. }\end{array}$ & $\begin{array}{l}\text { Subscribing to SM/ } \\
\text { groups (with a } \\
\text { possibly opposing } \\
\text { narrative) for } \\
\text { consumption } \\
\text { purposes. }\end{array}$ & $\begin{array}{l}\text { Constructing a } \\
\text { diverse feed (people } \\
\text { with opposing } \\
\text { views). Having SM } \\
\text { friends from abroad } \\
\text { for purposes of } \\
\text { news consumption. } \\
\text { Following (local) } \\
\text { politicians from } \\
\text { other countries. } \\
\text { Joining opposing } \\
\text { groups (to keep up } \\
\text { with the informa- } \\
\text { tion). }\end{array}$ \\
\hline $\begin{array}{l}\text { Example } \\
\text { quota- } \\
\text { tions }\end{array}$ & $\begin{array}{l}\text { I stopped using VK } \\
\text { after it was banned, } \\
\text { I guess because I am } \\
\text { too lazy to deal with } \\
\text { all these getting- } \\
\text { around systems, so } \\
\text { everything moved } \\
\text { to FB. [Interview 8] }\end{array}$ & $\begin{array}{l}\text { Right after these } \\
\text { events [Maidan } \\
\text { - O. N.] I started } \\
\text { subscribing to } \\
\text { Ukrainian groups. } \\
\text { Then I got much } \\
\text { more Ukrainian } \\
\text { content in my feed. } \\
\text { [Interview 1] }\end{array}$ & $\begin{array}{l}\text { VK for me is, firstly, } \\
\text { entertainment } \\
\text { content, then some } \\
\text { Russian financial } \\
\text { and technical news, } \\
\text { some local stuff, like } \\
\text { websites about } \\
\text { bicycles, traveling, } \\
\text { things that interest } \\
\text { me, music, etc. } \\
\text { [Interview 12] }\end{array}$ & $\begin{array}{l}\text { If something really } \\
\text { interesting [news } \\
\text { — O. N.] happens, I } \\
\text { have different } \\
\text { people in the feed } \\
\text { - patriots, left and } \\
\text { right activists - I } \\
\text { will know the } \\
\text { opinions from all } \\
\text { sides [...] I have } \\
\text { Russian activists in } \\
\text { friends, a famous } \\
\text { Russian feminist } \\
\text { - if something } \\
\text { happens in the } \\
\text { sphere of family } \\
\text { politics [...] I will } \\
\text { know about it. } \\
\text { [Interview 9] }\end{array}$ \\
\hline
\end{tabular}

Note: SM - social media.

Source: Author.

Practices of low engagement homophily were rationalized through references to comfort and indifference toward which platform/resource to use. In that sense, respondents preferred not to engage with discussions on institutional constraints and reported no difficulties switching (e.g., from VK to FB).

Practices of high engagement homophily were rationalized through the context of a wider trend of "growing one's Ukrainian identity" and loyalty to the state 
at the backdrop of the conflict. Russian sources/platforms/content are distanced from and viewed not necessarily as "enemy territory," but rather as unnecessary and irrelevant, since they retranslate the opposing narrative. This distancing can be additionally understood as a push away from the entanglement of Russian and Ukrainian content, as arguably:

You can try not reading it, but it's everywhere. There is no hiding. Ukrainian sources write a lot about Russian news. [Interview 11]

Instances of distancing from Russian content illustrated previous research conclusions (Kuzio, 2015; Kulyk, 2019) on the effect of the Euromaidan on the Ukrainian public narrative in terms of "breaking up" with Russia.

Practices of low engagement heterophily were rationalized through similar references to comfort and entertainment (platforms like VK providing specific possibilities to these ends).

Practices of high engagement heterophily were rationalized through references to the need (and right) to get a full spectrum of information from all sides to form a position. This is especially topical in the context of very low trust in the media both Ukrainian and Russian - across the Ukrainian population. In respondents' narratives, a high value was placed on shaping the network in such a way as to have personal sources to provide the local perspective or a certain degree of news pre-selection.

\section{Communication practices}

Personal communication is an important function of the digital media, and respondents' accounts showed that it is vital for hybrid users for maintaining connection with various audiences. Respondents provided multiple examples of hybrid communication - from keeping connected with relatives on occupied territories through digital tools, engaging with friends and acquaintances who moved abroad through social media, interacting with colleagues from neighboring countries (especially Russia) and communicating with half-strangers in the comment sections. Of course, these presuppose different degrees of closeness in communication - the closer the relationship with a person is, the higher the stakes for discussing political/civic issues. In the end, especially in the case of internally displaced persons, their digital communication practices reflected their ambiguous current position - on the one hand, support for Ukraine (the choice of moving to Kyiv, and not to Russia), on the other hand, the remainder of ties connecting them to the "other" side, to people who stayed, or to those living in Russia. Such an in-between position forces them to engage or disengage with both narratives in a variety of ways. Respondents' accounts provided some examples of hybrid engagement with both opposing narratives (pro-Ukrainian and pro-Russian) via different communication channels. For example, one respondent recalled entering into discussions with other users in the social media from - formally - two different standpoints: 
I engaged in commenting once in 2014. Oh no, twice last year as well [...]. In 2014 in one Crimean group a man was saying things about Kyiv, that were simply not reasonable, and I pointed it out to him and even almost changed his mind. I almost got him to agree with me, but then somebody again commented about fascists, and he went on. The other time, there was a woman [...]. I have a friend who lived in Crimea and now moved to Ukraine [na Ukrainu]. And somebody wrote about "na Ukrainu" and "v Ukrainu" [debate that to support independence of Ukraine as a state you should say "v Ukrainu" - O. N.], and I just couldn't stay silent. I was in a good mood and wanted to answer [...]. I wrote to her that it's the Russian language and it has nothing to do with it [seeing Ukraine as not an independent state - O. N.], and it doesn't diminish her dignity. [Interview 11]

Low engagement homophily practices were rationalized as simply the "state of things"; the absence of connections to Russia and unity among the audience mean that there is no need to engage in hybrid communication practices.

Rationalizations for high engagement practices of homophily, however, made clear references to the two narratives and the clash between them. In that sense, stopping communication with a person "from the other side" was seen as a clear act of self-distancing, "giving up" on the idea of finding consensus, as well as supporting one's position in a new (post-change) Ukrainian narrative space.

Low engagement acts of heterophily were discussed in the context of one's image as a "mediator," a person who is "above politics." The other elements included selfpositioning as a civilized internet user who cannot be "triggered," and references to the general need to avoid conflict in a high-tension environment. High engagement acts of heterophily reflected a general sense of ease about engaging in the discourses of other users:

I comment, answer if the question relates to me, or if I am being asked a question, or if there is an acute provocation and I can react funnily or troll them, so yeah, I do it pretty often. [Interview 10]

References were made to "truth-seeking," rationality and the universal human rights discourse - freedom to express opinion. It can be suggested that these practices form a basis for an identity of an active "civic" user with a "rational" position. In another sense, active public communication and open confidence to engage in heated discussions signifies high status and dominance in social media. The study results related to communication practices are summarized in Table 3.

Table 3. Findings: communication practices

\begin{tabular}{|c|c|c|c|c|}
\hline & $\begin{array}{l}\text { Low engagement } \\
\text { homophily }\end{array}$ & $\begin{array}{l}\text { High engagement } \\
\text { homophily }\end{array}$ & $\begin{array}{l}\text { Low engagement } \\
\text { heterophily }\end{array}$ & $\begin{array}{l}\text { High engagement } \\
\text { heterophily }\end{array}$ \\
\hline Practices & $\begin{array}{c}\text { No need for } \\
\text { modifying } \\
\text { communication } \\
\text { practices. }\end{array}$ & $\begin{array}{l}\text { Stopping commu- } \\
\text { nication with a } \\
\text { person (of an } \\
\text { opposing } \\
\text { narrative). }\end{array}$ & $\begin{array}{l}\text { Communicating } \\
\text { with diverse } \\
\text { audiences (from } \\
\text { Russia, other } \\
\text { post-soviet } \\
\text { countries, } \\
\text { occupied } \\
\text { territories), but } \\
\text { avoiding politics. }\end{array}$ & $\begin{array}{l}\text { Communicating } \\
\text { with diverse } \\
\text { audiences (from } \\
\text { Russia, other } \\
\text { post-soviet } \\
\text { countries, } \\
\text { occupied } \\
\text { territories), } \\
\text { discussing politics. }\end{array}$ \\
\hline
\end{tabular}




\begin{tabular}{|c|c|c|c|c|}
\hline $\begin{array}{c}\text { Example } \\
\text { quota- } \\
\text { tions }\end{array}$ & $\begin{array}{l}\text { Guys find some- } \\
\text { thing and send to } \\
\text { our chat [in } \\
\text { Telegram - O. N.], } \\
\text { and from there I } \\
\text { receive interesting } \\
\text { information, } \\
\text { because in general } \\
\text { we share the same } \\
\text { interests and } \\
\text { hobbies [...]. If we } \\
\text { discuss politics, } \\
\text { then very rarely [...] } \\
\text { Rather not, then } \\
\text { yes. [Interview 1] }\end{array}$ & $\begin{array}{l}\text { Unfortunately, with } \\
\text { one sister I } \\
\text { completely stopped } \\
\text { communicating, } \\
\text { because there were } \\
\text { such internet battles } \\
\text { at one point in time, } \\
\text { like } 2014,2015 \text {, very } \\
\text { serious ones. } \\
\text { [Interview } 7 \text { ] }\end{array}$ & $\begin{array}{l}\text { I wouldn't say that } \\
\text { we discuss politics. I } \\
\text { of course hear some } \\
\text { information from } \\
\text { them about their } \\
\text { political situation } \\
\text { and even their } \\
\text { opinions about } \\
\text { Ukraine, but we } \\
\text { don't hold discus- } \\
\text { sions [...]. We don't } \\
\text { discuss this, because } \\
\text { I have a fear that } \\
\text { they won't under- } \\
\text { stand me. [Inter- } \\
\text { view } 8]\end{array}$ & $\begin{array}{l}\text { We argue a lot in } \\
\text { comments with this } \\
\text { guy [...]. He is very } \\
\text { naïve and radical, } \\
\text { but I have known } \\
\text { him for a long time, } \\
\text { I know that he is a } \\
\text { good and smart guy, } \\
\text { and it is interesting } \\
\text { for me to discuss } \\
\text { things with him. } \\
\text { [Interview 12] }\end{array}$ \\
\hline
\end{tabular}

Source: Author.

\section{Content consumption practices}

Supporting the fact that for quite some time the Ukrainian media-scape has been dominated by Russian-language content, respondents' practices in the pre-Maidan period manifested high consumption of content that was regarded as neutral but often originated from Russia. Euromaidan, expectedly, was conceptualized as a rift, a breaking point, from which some practices developed in three distinct ways.

Some respondents reported eliminating the Russia-related, Russian origin or "controversial" in Ukrainian context (pro-Russian sources) content from their information flow. Content consumption was politicized in the sense that consuming "Ukrainian" content was rationalized as an act of loyalty. Purposeful consumption served as a basis for the identity of a loyal citizen, and consumption, as a political act, equaled support in the logic of rationalization. Additionally, the same distancing from Russia-related content can be understood as a reinstatement of dominance - in other words, events in Russia are not related to life in Ukraine.

The practices of low engagement heterophily included respondents consuming entertaining content from sources from other countries, without noticing/ engaging with their narratives (if there were any). As noted by one respondent, Russian-language content still remains very popular in the post-Soviet space, and many content creators strive to keep their work politics-free, otherwise they lose part of the audience. These practices are rationalized through de-politicization of the language - in other words, if the content does not involve any anti-Ukrainian narratives and is of high quality (to the user), there is no need to change the practices just on the basis of the language and/or country of origin. This rationalization strategy runs in opposition to the previous one, and can be seen as an attempt to de-securitize a part of the discourse and shift the boundary between "own" and 
"enemy" territory away from cultural elements (language) to the political ones (values, narratives).

Practices of high engagement heterophily involved purposeful political consumption of information that could have contained opposing narratives. On the one hand, users still reported a high capacity to discern between various narratives and "sift" the content based on key words and source reputation:

There are many weird words: vatniki [derogative for pro-Russian supporters - O. N.], imperzi [supporters of the Russian empire - O. N.], democrats, usually I understand that it's hysterical news. [Interview 12]

Additionally, more neutral and liberal content (e.g., Meduza, Dozhd, Lentach) is given preference over state-controlled content. However, here is how one respondent rationalizes the interest in political developments in Russia and Belarus:

I was just recently discussing this [why the user is interested in the news from Ukraine, Russia and Belarus - O. N.] in Facebook comments with one acquaintance, about Russia, that it's a big country with a population four times bigger than ours. And we live in a country where 4 banks out of 10 are Russian, 2 mobile operators are Russian, where there are many Russian cafes, restaurants, financial, insurance companies, where we have deputies with Russian passports. I cannot say that we live in a separate country, that's why in fact to know what happens here, it is important for me to know what is happening there. [Interview 12]

This narrative, arguably quite problematic in the current Ukrainian context, also runs contrary to the rationalization of high engagement acts of homophily, but, at the same time, it makes references to the concepts of civic duty and civic awareness:

Our [Ukrainian - O. N.] politicians condemn what happens in Russia with the right hand, but with the left hand they implement all the "best" Russian legislative initiatives, while denying their connection to Russia [... I I was just reading today a little bit that from the autumn mobile SIMcards will be sold only with passports here, like in Russia; that we will be limited in sending packages abroad, like in Russia; that we will have additional financial control, like in Russia; that sites will be blocked, like in Russia, etc. All the worst stuff that is happening in Russia is being transferred here. [Interview 12]

When taken as a whole, the narrative above is an example of an in-between position that criticizes both Ukrainian and Russian authorities from a civic, post-national position, making reference to the right to consume and comment news from any country. However, I would argue that there is no significant blurring of the state boundary here, as the respondent clearly refers to "our politicians." It rather seems that the respondent wants to draw an additional boundary - a value-based one - between Russia (associated with control of information) and Ukraine (which now positions itself as Westand freedom-oriented) by formulating a claim/criticism to the authorities. The study results on content consumption practices are summarized in Table 4. 
Table 4. Findings: content consumption practices

\begin{tabular}{|c|c|c|c|c|}
\hline & $\begin{array}{c}\text { Low engagement } \\
\text { homophily }\end{array}$ & $\begin{array}{l}\text { High engagement } \\
\text { homophily }\end{array}$ & $\begin{array}{l}\text { Low engagement } \\
\text { heterophily }\end{array}$ & $\begin{array}{l}\text { High engagement } \\
\text { heterophily }\end{array}$ \\
\hline Practices & $\begin{array}{l}\text { Consuming } \\
\text { homogenous } \\
\text { content (due to } \\
\text { comfort). }\end{array}$ & $\begin{array}{l}\text { Switching to more } \\
\text { homogenous } \\
\text { content (choosing } \\
\text { own narrative } \\
\text { news sources, } \\
\text { discontinuing } \\
\text { opposing } \\
\text { narrative } \\
\text { sources). }\end{array}$ & $\begin{array}{c}\text { Consuming } \\
\text { entertainment/ } \\
\text { educational web } \\
\text { content (text and } \\
\text { video based, } \\
\text { following celebri- } \\
\text { ties) from other } \\
\text { countries (includ- } \\
\text { ing with opposing } \\
\text { narratives). }\end{array}$ & $\begin{array}{c}\text { Consuming } \\
\text { political content/ } \\
\text { news (text and } \\
\text { video based) from } \\
\text { other countries } \\
\text { (including with } \\
\text { opposing } \\
\text { narratives). }\end{array}$ \\
\hline $\begin{array}{l}\text { Example } \\
\text { quotations }\end{array}$ & Not detected & $\begin{array}{l}\text { When the } \\
\text { "Hromadske } \\
\text { telebachennya" } \\
\text { channel appeared } \\
\text { during the Maidan } \\
\text { times, I started } \\
\text { following streams } \\
\text { from the Maidan } \\
\text { and still watch it } \\
\text { [...]. After the } \\
\text { Maidan I stopped } \\
\text { watching Inter, 5th } \\
\text { Channel, 1+1. } \\
\text { [Interview 10] }\end{array}$ & $\begin{array}{l}\text { Well, what I read } \\
\text { regularly is Snob, it's } \\
\text { a Russian outlet, they } \\
\text { have very interesting } \\
\text { ideas, also I read one } \\
\text { interesting site called } \\
\text { Royal Cheese. } \\
\text { [Interview 12] } \\
\text { I am watching } \\
\text { bloggers on YouTube, } \\
\text { non-political ones } \\
\text { [...]. I think they are } \\
\text { Russians, who live } \\
\text { somewhere outside } \\
\text { of Russia. But } \\
\text { blogging is just more } \\
\text { developed in Russia, I } \\
\text { don't even know } \\
\text { Ukrainian, especially } \\
\text { Ukrainian-speaking, } \\
\text { bloggers. [Interview 9] }\end{array}$ & $\begin{array}{l}\text { I am reading } \\
\text { "Belorussian } \\
\text { partisan," "Our } \\
\text { niva," also a } \\
\text { Belorussian portal, } \\
\text { Varlamov, it's a } \\
\text { Russian blogger, he } \\
\text { writes a lot, not only } \\
\text { about politics, but } \\
\text { also about urban } \\
\text { design [...]. Also } \\
\text { Artemiy Lebedev, } \\
\text { groups that } \\
\text { migrated from VK } \\
\text { - Lentach [Russian } \\
\text { liberal news - } \\
\text { O. N.], Novinach } \\
\text { [Ukrainian } \\
\text { equivalent - } \\
\text { O. N.], Belorussian } \\
\text { project “Tea with } \\
\text { raspberry jam," they } \\
\text { write a lot about } \\
\text { Belorussian politics } \\
\text { and maybe a dozen } \\
\text { more channels, so } \\
\text { yeah, I read news } \\
\text { from there. } \\
\text { [Interview 12] }\end{array}$ \\
\hline
\end{tabular}

Source: Author. 


\section{Content creation practices}

Content creation practices are usually not so widespread among users as other practices, as they require a degree of self-awareness and confidence. Especially in a conflict context, one might be hesitant to disclose one's opinion at the backdrop of institutional and semi-public pressure to streamline one's digital self-presentation.

In terms of high engagement heterophily, the practices detected mostly concerned switching to Ukrainian in posts and creating content that focuses on the narrative of supporting Ukraine in times of crisis. It can be suggested that such practices are rationalized similarly - along the lines of support to the state. Low engagement acts of heterophily - posting and reposting entertaining content that in some way crosses the boundary between states without bringing in the political component - and high engagement acts of heterophily were in some ways rationalized, contextually, through similar strategies:

a) desire to "save" something, make a memory, so that it is not lost;

b) desire to "retranslate" one's views on the subject to the audience.

However, in the context of high engagement acts of heterophily, respondents also referred to reflection - digital media as a space for reflection - as playing an important role in why they create content. As users with different degrees of hybrid experiences and practices (ties to Russia, occupied territories, internally displaced person status, etc.), they themselves constituted elements challenging to the mainstream discourse. The digital media space, therefore, was used as a tool for selfreflection and re-integration of oneself into the public narrative, which in its turn, changes with each such re-negotiation and re-integration:

What I write here mostly, I guess, is my vision and some reflection as a person from Donetsk, Luhansk, who lives in Kyiv now [...]. I see it as an element of my social path, that I intentionally don't go and get IDP status, because I still consider myself a citizen of Ukraine, not a citizen of Luhansk or Kyiv and this is my position. So that you can read in my reflections - some of my memories. [Interview 8]

Both examples (as well as the one in the table, with a list of "What it means to be an IDP (internally displaced person)") resist the simplistic interpretation of themselves and, instead, offer a critique to the existing order, even though through digital micropractices. A results overview in this part of the study is summarized in Table 5. 
Table 5. Findings: content creation practices

\begin{tabular}{|c|c|c|c|c|}
\hline & $\begin{array}{l}\text { Low engagement } \\
\text { homophily }\end{array}$ & $\begin{array}{l}\text { High engagement } \\
\text { homophily }\end{array}$ & $\begin{array}{l}\text { Low engagement } \\
\text { heterophily }\end{array}$ & $\begin{array}{l}\text { High engagement } \\
\text { heterophily }\end{array}$ \\
\hline Practices & $\begin{array}{l}\text { No changes in } \\
\text { content creation. }\end{array}$ & $\begin{array}{l}\text { Switching to the } \\
\text { state language } \\
\text { (Ukrainian) in } \\
\text { posts. }\end{array}$ & $\begin{array}{c}\text { Sharing } \\
\text { entertainment } \\
\text { content from } \\
\text { other countries } \\
\text { (including ones } \\
\text { with an opposing } \\
\text { narrative). } \\
\text { Commenting on } \\
\text { posts in a } \\
\text { different } \\
\text { language } \\
\text { (Russian). }\end{array}$ & $\begin{array}{l}\text { Blogging/posting } \\
\text { challenging } \\
\text { content on social } \\
\text { and political } \\
\text { issues (regarding } \\
\text { Ukraine, } \\
\text { Donbass, } \\
\text { Crimea, Russia } \\
\text { and other). } \\
\text { Sharing/ } \\
\text { encouraging } \\
\text { discussions on } \\
\text { Russian news. } \\
\text { Blogging/posting } \\
\text { self-reflections } \\
\text { on issues of } \\
\text { politics and } \\
\text { identity. }\end{array}$ \\
\hline $\begin{array}{c}\text { Example } \\
\text { quotations }\end{array}$ & $\begin{array}{l}\text { If I'm posting } \\
\text { something, I do it } \\
\text { in Ukrainian. } \\
\text { [Interview 7] }\end{array}$ & $\begin{array}{l}\text { It's interesting - I } \\
\text { followed this } \\
\text { blogger [on } \\
\text { Facebook] before, } \\
\text { and sometimes he, } \\
\text { you know, shares } \\
\text { his own older } \\
\text { posts. He used to } \\
\text { be writing in } \\
\text { Russian, now he } \\
\text { writes in Ukrai- } \\
\text { nian. [Interview 9] }\end{array}$ & $\begin{array}{l}\text { These are some } \\
\text { photos from an } \\
\text { exhibition in } \\
\text { Vladivostok, in a } \\
\text { sea port, some } \\
\text { crazy stuff is } \\
\text { happening. I didn't } \\
\text { understand it, but } \\
\text { I liked the guy in a } \\
\text { funny picture. } \\
\text { [Interview 12] }\end{array}$ & $\begin{array}{l}\text { I had it [a blog } \\
\text { about being an } \\
\text { IDP - O. N.] for } \\
\text { one and a half } \\
\text { years [...]. First it } \\
\text { was just bits and } \\
\text { pieces of my life, } \\
\text { but then I sat down } \\
\text { and wrote what it } \\
\text { means for me to be } \\
\text { an internally } \\
\text { displaced person } \\
\text { [...]. In the end it } \\
\text { was a list compiled } \\
\text { and amended by } \\
\text { many people from } \\
\text { Ukraine [...]. The } \\
\text { list was in the mass } \\
\text { media, in Donetsk } \\
\text { [...]. I remember } \\
\text { people from } \\
\text { Australia, } \\
\text { Germany, Canada } \\
\text { writing to me } \\
\text { "thank you." } \\
\text { [Interview 3] }\end{array}$ \\
\hline
\end{tabular}

Source: Author. 


\section{DISCUSSION AND CONCLUSIONS}

The above analysis provided an overview of the dynamics of national identity negotiation and re-production through digital media practices by using the example of Russian-speaking Ukrainians in the context of conflict between Ukraine and Russia. While the conflict created conditions conducive to media homophily (active nation-building, distancing from Russia, a ban on Russian resources), the digital media practices showed that hybridity is still maintained through users' networks and other micro-level mechanisms. Far from being passive receivers of pressure, users exercised their agency by re-shaping their media environment to better suit their needs and identity (unsubscribing, unfollowing, deleting from friends and, ultimately, changing the platform).

The analysis of rationalization strategies for digital media practices focused on two main issues: heterophily in information channels and engagement. The mapping of practices (developing the conceptualization of Couldry using social practice theory) is presented in Figure 2. As a result of the analysis, I concluded that heterogeneous and homogeneous practices with high levels of engagement produced separate narratives of national identity in post-conflict Ukraine.

Both viewed some digital media practices (posting, sharing news, other public digital activities) as constitutive expressions of their larger offline identities. However, the practices characterized by high engagement and homophily were rationalized through references to the need to "grow" one's Ukrainian identity and support the state - thus being nation-centric. High engagement heterophily, however, was rationalized through references to universal human rights/values discourse, and thus, national identity in this narrative was conceptualized from the post-national and universalizing positions.

Practices characterized by low engagement and both homophily and heterophily were rationalized using references to "comfort" and one's own given nature. However, there was an important distinction in the case of low engagement/heterophily, where users' explanations can be interpreted as efforts to de-politicize - mostly, communication and consumption of content from the "Other" side, as a response to state narratives growing more ethno-centric (Hutchings \& Szostek, 2015; Teper, 2016). These practices can be viewed as attempts to de-securitize issues of ethnicity - language, country of origin, culture - in their manifestations in the digital mediasphere (Trošt \& Mandić, 2017).

The analysis of low engagement and high engagement heterophily in practices supported the assumptions of Gil de Zúñiga et al. (2012) that entertainment activities bear lower levels of transformativity than such practices as news consumption. Communication with persons from "the Other" side was also either politicized or deliberately de-politicized by respondents, which only supports the conclusion that the conflict actualized a divide between symbolic communities of Ukraine and Russia, and the communication domain remained a contentious negotiation 


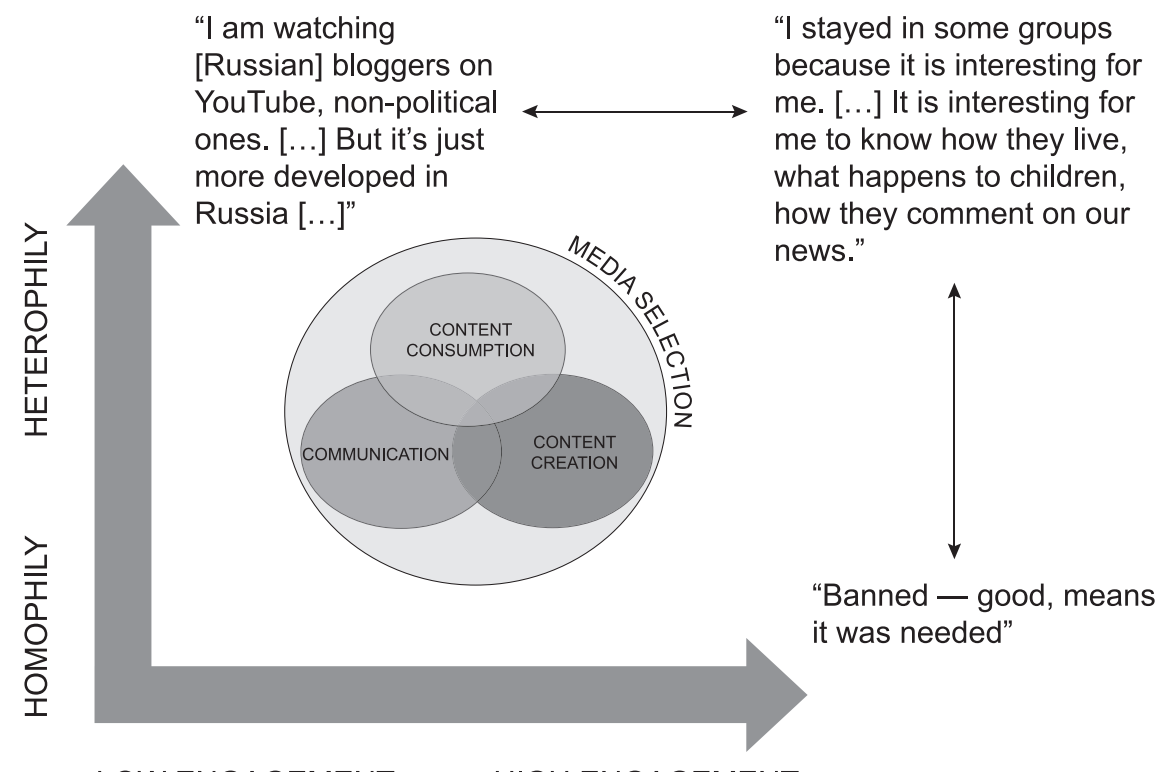

LOW ENGAGEMENT

HIGH ENGAGEMENT

Figure 2. Mapping of digital media practices across dimensions of heterophily and engagement

Source: Author.

territory for hybrid users (Nedozhogina, 2019; Kulyk, 2018). The content creation domain provided space for users to not only re-conceptualize their hybridity in the emerging national identity narrative of Ukraine, but also to re-translate their views to the rest of the audience. We can assume that this is motivated by the post-conflict precariousness of the in-between position of hybrid respondents.

The choice to construct a feed with a diversity of perspectives ("to see what's happening on the other side") served as a basis for users' identity as knowledgeable (media) citizens, while in cases of high engagement homophily - as loyal supporters of the country in conflict. Media practices were, therefore, securitized to a degree even on the lay level, however, with significant manoeuver room for hybrid users.

\section{REFERENCES}

Aksoy, A., \& Robins, K. (2002). Banal transnationalism: The difference that television makes. Oxford: University of Oxford, Transnational Communities Programme.

Anderson, B. (2006). Imagined communities: Reflections on the origin and spread of nationalism. New York: Verso Books.

Andersson, M. (2013). Multi-contextual lives: Transnational identifications under mediatised conditions. European Journal of Cultural Studies, 16(4), 387-404.

Bennett, W. L., \& Segerberg, A. (2012). The logic of connective action: Digital media and the personalization of contentious politics. Information, Communication \& Society, 15(5), 739-768.

Chadwick, A. (2017). The hybrid media system: Politics and power. Oxford: Oxford University Press. 
Collin, P. (2014). Digitally enhanced? Mediated migration and 'fourth wave' Chileans in Australia. Journal of Intercultural Studies, 35(5), 532-548.

Couldry, N. (2012). Media, society, world: Social theory and digital media practice. Cambridge, UK: Polity.

Gil de Zúñiga, H., Jung, N., \& Valenzuela, S. (2012). Social media use for news and individuals' social capital, civic engagement and political participation. Journal of Computer-Mediated Communication, 17(3), 319-336.

Gu, B., Konana, P., Raghunathan, R., \& Chen, H. M. (2014). Research note - The allure of homophily in social media: Evidence from investor responses on virtual communities. Information Systems Research, 25(3), 604-617.

Hutchings, S., \& Szostek, J. (2015). Dominant narratives in Russian political and media discourse during the Ukraine crisis. In Ukraine and Russia: People, politics, propaganda and perspectives (pp. 173-185). Bristol, UK: E-International Relations.

Kulyk, V. (2019). Identity in transformation: Russian-speakers in post-Soviet Ukraine. Europe-Asia Studies, 71(1), 156-178.

Kulyk, V. (2018). Between the "Self" and the "Other": Representations of Ukraine's Russian-speakers in social media discourse. East/West: Journal of Ukranian Studies, 5(2), 65-88.

Kuzio, T. (2015). Competing nationalisms, Euromaidan, and the Russian-Ukrainian conflict. Studies in Ethnicity and Nationalism, 15(1), 157-169.

Nedozhogina, O. (2019). Redrawing symbolic boundaries after Maidan: Identity strategies among Russian-speaking Ukrainians. In National identities, forthcoming.

Papacharissi, Z. (2015). Affective publics: Sentiment, technology, and politics. Oxford: Oxford University Press.

Reckwitz, A. (2002). Toward a theory of social practices: A development in culturalist theorizing. European Journal of Social Theory, 5(2), 243-263.

Shove, E., \& Pantzar, M. (2005). Consumers, producers and practices: Understanding the invention and reinvention of Nordic walking. Journal of Consumer Culture, 5(1), 43-64.

Szostek, J. (2017). The power and limits of Russia’s strategic narrative in Ukraine: The role of linkage. Perspectives on Politics, 15(2), 379-395.

Szostek, J. (2018). Nothing is true? The credibility of news and conflicting narratives during "information war" in Ukraine. The International Journal of Press/Politics, 23(1), 116-135.

Teper, Y. (2016). Official Russian identity discourse in light of the annexation of Crimea: National or imperial? Post-Soviet Affairs, 32(4), 378-396.

Trošt, T. P., \& Mandić, D. (2017). Introduction: Beyond ethnicity in research on youth in Southeast Europe. In T. Trošt \& D. Mandić (Eds.), Changing youth values in Southeast Europe (pp. 1-15). London: Routledge.

Vertovec, S. (2001). Transnationalism and identity. Journal of Ethnic and Migration Studies, 27(4), 573-582.

Vihalemm, T., Juzefovičs, J., \& Leppik, M. (2019). Identity and media-use strategies of the Estonian and Latvian Russian-speaking populations amid political crisis. Europe-Asia Studies, 71(1), 48-70.

Wessels, B. (2018). Communicative civic-ness: Social media and political culture. New York: Routledge. 